\title{
Comparison of Petiole Nutrient Contents of Different Table and Wine Grape Varieties
}

\author{
Anita E. Kondi*, Shankar Meti, B.V. Champa and M.S. Nagaraja \\ College of Horticulture, University of Horticultural Sciences, Bagalkot - 587 104, \\ Karnataka, India \\ *Corresponding author
}

\begin{abstract}
A B S T R A C T
Keywords

Grape, Petiole analysis, Nutrients,

Table grapes, Wine grapes

Article Info

Accepted:

06 December 2017

Available Online:

10 January 2018

A study was conducted to know the petiole nutrient content in different grape genotypes belonging to table purpose white and coloured types along with wine grape types. Petiole nutrient contents among three different grapes types varied significantly. Petiole $\mathrm{P}, \mathrm{K}, \mathrm{Mn}$ and $\mathrm{Zn}$ contents among the three grape types varied in the order: table white > table coloured > wine grape. Petiole $\mathrm{P}, \mathrm{Ca}, \mathrm{Mn}$ and $\mathrm{Cu}$ content of wine and table purpose white type differed significantly, where as other macro and micro nutrients did not differ significantly. Table purpose white varieties recorded significantly higher $\mathrm{P}, \mathrm{Mn}$ and $\mathrm{Cu}$ content in petiole compared to wine grape. Ca content was found highest in wine grape compared to table white and coloured grape. Table white grape recorded significantly higher $\mathrm{P}(0.35 \%)$ and $\mathrm{S}(0.12 \%)$ content compared to coloured type $(0.25 \% \mathrm{P}$ and $0.07 \% \mathrm{~S}$ ). The hierarchical cluster analysis revealed two distinct grapes group. Comparison made of wine types is one cluster and table types is the another cluster.
\end{abstract}

\section{Introduction}

Grape (Vitis vinifera L.) is one of the most economically important fruit crops (Ruel and Walker, 2006). Its cultivation is believed to have originated in Armenia near the Caspian Sea in Russia. Later, it appears to have spread westward to Europe and eastward to Iran and Afghanistan. Muslim invaders from Iran and Afghanistan introduced grapes to India during 1300 A.D. (Thapar, 1960). However, the crop is well acclimatized for the Indian subcontinent possessing sub-tropical and tropical agro climatic conditions and now, viticulture is being practiced as one of the most remunerative farming enterprises. Petiole nutrient analysis, at a particular stage during the plant growth, is being used since long time as a tool to assess grape quality and its yield potentiality. However, successful nutrient management in grapes is determined by both soil and plant analyses together, instead of one method alone (Marschner, 1995). The genetic makeup of grape genotypes for table purpose and wine types are very different (Zoë Migicovsky et al.,, 2017) and hence, the fruit berries at harvest and the plant (petiole) nutrient contents at different growth stages are expected to be very distinct (Bertoni $G$ and Morard P, 1982). Petiole analysis at bloom 
stage could be used as a diagnostic tool for grape quality and to introduce midterm corrections, if needed, through nutrient applications. Considering these importance, a study was carried out to assess petiole nutrient contents among wine and table grape varieties existing at the University campus and analysed their similarities across major grape types.

\section{Materials and Methods}

\section{Location}

An experiment was conducted at Main Horticultural Research and Extension Centre (MHREC), Bagalkot, Karnataka during 201415. The MHREC farm is situated at $16^{\circ} 46^{\prime}$ North and $74^{\circ} 59^{\prime}$ East receiving an average annual rainfall of about $580 \mathrm{~mm}$. The University farm has 23 different grape genotypes comprising of both table purpose and wine grape types for growth performance evaluation. The grape plants at the farm are of 4 years old and they are trained on Y-trellies. The soils were red in colour with sandy loam texture. The soil reaction was found to be slightly alkaline (7.51-8.61) and possessed medium levels of soil fertility.

\section{Sample collection and analysis}

Grape petioles were sampled by adopting standard method as prescribed by IIHR (Bhargav, 2001). The leaves present on the opposite of the first inflorescence of the cane were chosen for petiole sampling (Patel and Chada, 2002). Petiole sampling was done in the morning hours at the rate of 3-4 leaves per plant and only the petioles were retained. Petiole sampling was done during the month of November to match it with 40-45 days after $2^{\text {nd }}$ pruning. Three sets of petiole samples were drawn separately for each variety. The fresh petioles were rinsed for 30 seconds in plastic trays having solutions of $0.1 \mathrm{~N} \mathrm{HCL}$, then with $1 \%$ detergent and finally, in distilled water (2 times) to remove all the adsorbed surface chemicals. These washed petioles were air dried for a day in shade and then, oven dried at $65^{\circ} \mathrm{Cfor} 48 \mathrm{hrs}$. The dried petioles samples were powdered in stainless steel jars using Kitchen Mixie and kept in air tight containers for further analysis.

\section{Nutrient analysis}

The petiole nitrogen content was determined by Kjeldhal distillation method (Piper, 1966). For other nutrients, $0.5 \mathrm{~g}$ of powdered petiole samples were separately digested in diacid mixture $\mathrm{HNO}_{3}: \mathrm{HClO}_{4}$ (10:4 ratio). The digested colourless solution was diluted to 100 $\mathrm{ml}$ and stored in airtight containers for further analysis. The methodologies adopted for estimation of different nutrients are presented in Table 1.

\section{Data analysis}

Finally nutrient content of petioles among different grape groups were compared using paired ' $t$ ' test and analyzed at 0.05 level of significance. Based on the petiole nutrient contents, different grape varieties were grouped into homogeneous groups, using hierarchical cluster analysis technique and expressed them in dendrograms.

\section{Results and Discussion}

The nitrogen content in grape petioles ranged from 1.11 per cent in a wine grape variety Tempranillo to 2.19 per cent in Krishna Sharad belonging to table purpose coloured grape variety (Table 2). Among three broad groups, petiole nitrogen content was found high in table purpose coloured grape types $(2.02 \pm 0.11 \%)$ and it was least in wine grapes $(1.39 \pm 0.15 \%)$. Petiole $-\mathrm{N}$ content did not differ significantly among 3 grape types (Table 3). 
The phosphorus content in grape petioles ranged from 0.10 per cent in Chenin Blanc wine grape variety to 0.32 per cent in Krishmish Rozavis white table grape variety. Among three broad groups, petiole phosphorus content was significantly higher in table grape white followed by coloured grape and wine grape types. Thus, petiole-P was found in the order : table white $>$ table coloured > wine grape types and their respective values were $0.24 \pm 0.06 \%, 0.23 \pm$ $0.03 \%$ and $0.15 \pm 0.02 \%$. Petiole $-\mathrm{P}$ content differed significantly among 3 grape types (Table 3).

The petioles of Tempranillo wine grape type recorded the lowest potassium content of 1.10 per cent while, white grape variety Manik Chaman recorded highest petiole-K content (2.38\%). Among different grape types, wine grapes recorded least potassium content (1.40 $\pm 0.14 \%)$, whereas table grape white $(2.09 \pm$ $0.18 \%)$ and coloured $(2.01 \pm 0.15 \%)$ recorded highest. Petiole $-\mathrm{K}$ content did not differ significantly among 3 grape types (Table 3 ).

The calcium content in grape petioles ranged from 1.08 per cent in Krishna Sharad and Crimson Seedless coloured table purpose grape varieties to 2.30 per cent in Sirius variety of wine grape type. Among three groups studied, highest calcium content was found in wine grapes (1.92 $\pm 0.27 \%)$, compared to petioles of table purpose white grape types $(1.30 \pm 0.15 \%)$ and coloured grape group $(1.23 \pm 0.21 \%)$. Calcium contents in grape petioles were found in the order: wine grapes $>$ table white grape $=$ table coloured grapes. Petiole - Ca content of wine grape type varied significantly with white and coloured table grape type (Table 3).

The magnesium content in grape petioles ranged from 0.40 per cent in table purpose colored Fantacy Seedless grape variety to 0.94 per cent in Kishmish Rozavish belonging to table purpose white grape types (Table 2). Among different grape groups, table purpose white type recorded higher amounts of magnesium $(0.75 \pm 0.16 \%)$ and least was found in table coloured grapes $(0.58 \pm 0.14 \%)$. However, petiole magnesium content did not differ significantly among 3 grape types.

The sulphur content in grape petioles ranged from 0.05 per cent in coloured table purpose Flame Seedless grape variety to 0.16 per cent in 2A Clone of table purpose white grape types (Table 2). The highest sulphur content was recorded in table purpose white type grape petioles with a mean of $0.12 \pm 0.02 \%$ while, petioles of table purpose coloured group recorded least sulphur content $(0.07 \pm$ $0.01 \%)$. Sulphur contents in petioles were found significantly different only between table white and coloured grape types (Table 3).

The iron content in grape petiole ranged from $65.80 \mathrm{ppm}$ in Tsimlaski Chernyi of wine grapes to $98.56 \mathrm{ppm}$ in Manik Chaman variety of table white grape type. Petiole iron content was significantly high in table purpose white grape $(83.87 \pm 9.61 \mathrm{ppm})$ and least iron content was recorded in table purpose coloured grapes group (75.99 $\pm 7.31 \mathrm{ppm})$. The petiole $-\mathrm{Fe}$ content did not differ significantly among 3 grape types (Table 3 ).

The manganese content in grape petioles ranged from $67.55 \mathrm{ppm}$ in coloured table purpose Red Globe variety to $105.35 \mathrm{ppm}$ in Manik Chaman variety belonging to table white grape type (Table 2). Among three broad groups, petiole manganese content was found in the order : table white $>$ table coloured $>$ wine grape types with respective mean values $100.98 \pm 10.56 \mathrm{ppm}, 94.55 \pm$ $13.20 \mathrm{ppm}$ and $90.22 \pm 8.51 \mathrm{ppm}$. However, petiole manganese content varied significantly only between wine and table white grape type (Table 3). 
Table.2a Petiole Nutrient contents of different grape varieties - Wine grape types

\begin{tabular}{|c|c|c|c|c|c|c|c|c|c|c|}
\hline \multirow[t]{2}{*}{ Wine grape types } & $\mathbf{N}$ & $\mathbf{P}$ & $\mathbf{K}$ & $\mathrm{Ca}$ & Mg & $\mathbf{S}$ & $\mathrm{Fe}$ & Mn & Zn & $\mathrm{Cu}$ \\
\hline & \multicolumn{6}{|c|}{ (in per cent) } & \multicolumn{4}{|c|}{ (ppm) } \\
\hline Cabernet & 1.46 & 0.16 & 1.46 & 2.25 & 0.69 & 0.09 & 78.85 & 88.71 & 102.30 & 16.67 \\
\hline Greenche Noir & 1.38 & 0.15 & 1.38 & 1.95 & 0.91 & 0.11 & 77.25 & 74.09 & 91.23 & 12.22 \\
\hline TsimlaskiChernyi & 1.23 & 0.13 & 1.32 & 1.60 & 0.77 & 0.09 & 65.80 & 86.19 & 89.36 & 19.60 \\
\hline Souvignon Blanc & 1.27 & 0.15 & 1.27 & 1.62 & 0.60 & 0.08 & 66.23 & 71.11 & 98.36 & 15.69 \\
\hline Bianca & 1.45 & 0.17 & 1.45 & 1.49 & 0.55 & 0.06 & 75.35 & 84.75 & 86.65 & 21.54 \\
\hline Greenche Blanc & 1.64 & 0.17 & 1.64 & 1.81 & 0.87 & 0.11 & 74.50 & 83.90 & 74.26 & 16.60 \\
\hline Sirius & 1.57 & 0.13 & 1.57 & 2.30 & 0.78 & 0.09 & 84.56 & 90.58 & 89.67 & 14.97 \\
\hline Chenin Blanc & 1.34 & 0.10 & 1.34 & 1.96 & 0.69 & 0.08 & 84.50 & 88.65 & 99.58 & 15.26 \\
\hline Tempranillo & 1.11 & 0.15 & 1.10 & 2.24 & 0.49 & 0.08 & 83.44 & 96.78 & 93.27 & 11.23 \\
\hline Shiraj & 1.46 & 0.16 & 1.46 & 1.92 & 0.54 & 0.12 & 73.29 & 85.66 & 89.59 & 12.31 \\
\hline Medika & 1.35 & 0.18 & 1.35 & 1.99 & 0.53 & 0.10 & 79.62 & 87.50 & 78.20 & 12.64 \\
\hline Mean & 1.39 & 0.15 & 1.40 & 1.92 & 0.67 & 0.09 & 76.67 & 85.27 & 90.22 & 15.34 \\
\hline S.D & 0.15 & 0.02 & 0.14 & 0.27 & 0.15 & 0.02 & 6.54 & 7.19 & 8.51 & 3.21 \\
\hline
\end{tabular}

Table.2b Petiole Nutrient contents of different grape varieties - Table grape types

\begin{tabular}{|c|c|c|c|c|c|c|c|c|c|c|}
\hline \multirow[t]{2}{*}{ Table grape types } & $\mathbf{N}$ & $\mathbf{P}$ & $\mathbf{K}$ & $\mathrm{Ca}$ & Mg & $\mathbf{S}$ & Fe & Mn & $\mathbf{Z n}$ & $\mathbf{C u}$ \\
\hline & \multicolumn{6}{|c|}{ (in per cent) } & \multicolumn{4}{|c|}{$(\mathrm{ppm})$} \\
\hline \multicolumn{11}{|c|}{ White grape type } \\
\hline Manjre Naveen & 1.97 & 0.24 & 2.00 & 1.35 & 0.62 & 0.10 & 78.16 & 85.47 & 96.36 & 25.63 \\
\hline $2 \mathrm{~A}$ clone & 1.82 & 0.28 & 2.18 & 1.17 & 0.90 & 0.16 & 73.66 & 97.61 & 84.79 & 29.54 \\
\hline KrishmishRozavish White & 1.92 & 0.32 & 1.96 & 1.13 & 0.94 & 0.12 & 81.69 & 90.07 & 107.20 & 22.27 \\
\hline Manikchaman & 2.02 & 0.20 & 2.38 & 1.33 & 0.66 & 0.10 & 98.56 & 105.35 & 111.25 & 29.97 \\
\hline Sonaka & 2.06 & 0.19 & 1.95 & 1.48 & 0.62 & 0.12 & 87.30 & 92.23 & 105.30 & 20.92 \\
\hline Mean & 1.96 & 0.24 & 2.09 & 1.30 & 0.75 & 0.12 & 83.87 & 94.15 & 100.98 & 25.67 \\
\hline S.D & 0.09 & 0.06 & 0.18 & 0.15 & 0.16 & 0.02 & 9.61 & 7.63 & 10.56 & 4.11 \\
\hline \multicolumn{11}{|c|}{ Colored grape type } \\
\hline Flame Seedless & 1.96 & 0.18 & 2.23 & 1.12 & 0.54 & 0.05 & 85.92 & 95.39 & 102.32 & 28.63 \\
\hline Sharad Seedless & 1.89 & 0.25 & 2.15 & 1.22 & 0.63 & 0.07 & 73.12 & 87.70 & 106.85 & 20.78 \\
\hline Krishna Sharad & 2.19 & 0.26 & 1.99 & 1.08 & 0.83 & 0.07 & 81.78 & 81.46 & 99.33 & 25.02 \\
\hline Fantacy Seedless & 2.04 & 0.26 & 1.85 & 1.23 & 0.40 & 0.08 & 78.61 & 80.97 & 102.48 & 28.59 \\
\hline Crimson Seedless & 2.17 & 0.21 & 1.88 & 1.08 & 0.54 & 0.07 & 67.98 & 77.32 & 73.92 & 29.65 \\
\hline Red Globe & 1.94 & 0.21 & 1.97 & 1.63 & 0.56 & 0.07 & 68.52 & 67.55 & 82.38 & 25.04 \\
\hline Mean & 2.02 & 0.25 & 2.01 & 1.23 & 0.58 & 0.07 & 75.99 & 81.72 & 94.55 & 26.28 \\
\hline S.D & 0.11 & 0.03 & 0.15 & 0.21 & 0.14 & 0.01 & 7.31 & 9.41 & 13.20 & 3.33 \\
\hline
\end{tabular}


Table.3 Comparison of petiole nutrient contents among wine and table purpose grape varieties

\begin{tabular}{|c|c|c|c|c|c|c|c|c|c|c|}
\hline Grape Type & $\mathbf{N}$ & $\mathbf{P}$ & $\mathbf{K}$ & $\mathbf{C a}$ & Mg & $\mathbf{S}$ & Fe & Mn & $\mathrm{Zn}$ & $\mathrm{Cu}$ \\
\hline & \multicolumn{6}{|c|}{ (in per cent) } & \multicolumn{4}{|c|}{ (in ppm) } \\
\hline Wine Grape & 1.39 & 0.15 & 1.40 & 1.92 & 0.67 & 0.09 & 76.67 & 85.27 & 90.22 & 15.34 \\
\hline Table White Grape & 1.96 & 0.24 & 2.09 & 1.30 & 0.75 & 0.12 & 83.87 & 94.15 & 100.98 & 25.67 \\
\hline Table Coloured Grape & 2.02 & 0.23 & 2.01 & 1.23 & 0.58 & 0.07 & 75.99 & 81.72 & 94.55 & 26.28 \\
\hline \multicolumn{11}{|c|}{ Comparison of means with respective 't' values } \\
\hline Wine X Table white & 1.81 & $4.87 *$ & 0.41 & $6.30^{*}$ & 0.75 & 2.14 & 0.43 & $2.56 *$ & 2.00 & $4.98 *$ \\
\hline Wine X Table coloured & 0.48 & $7.14^{*}$ & 1.20 & $5.75^{*}$ & 1.25 & 2.00 & 1.07 & 0.44 & 0.92 & $6.55^{*}$ \\
\hline Table White X Table coloured & 1.23 & $2.43 *$ & 0.93 & 0.55 & 1.50 & $5.00 *$ & 1.29 & 1.35 & 0.89 & 0.26 \\
\hline
\end{tabular}

Fig.1 Hierarchical cluster analysis of different grape types based on petiole nutrient contents

Rescaled Distance Cluster Combine

C A S E Label

Sauvignon blan Chenin blanc

a Tempranillo

2 Shiraj

\# Medika

Q Bianca.

\$ Greenche noir

$\leq$ Sirius

I Greenche blanc Tsimlaski Cher Crimson seedle Red globe Sharad seedles Krishna sharad Flame seedless Manjre naveen Fantacy seedle Kritenmish roza rishmish roza lanik chaman Sonaka $2 \mathrm{~A}$ clone
5

Num
4
8
9
10
11
1
5
2
7
6
3
21
22
18
19
17
12
20
14
15
16
13

o

15

20

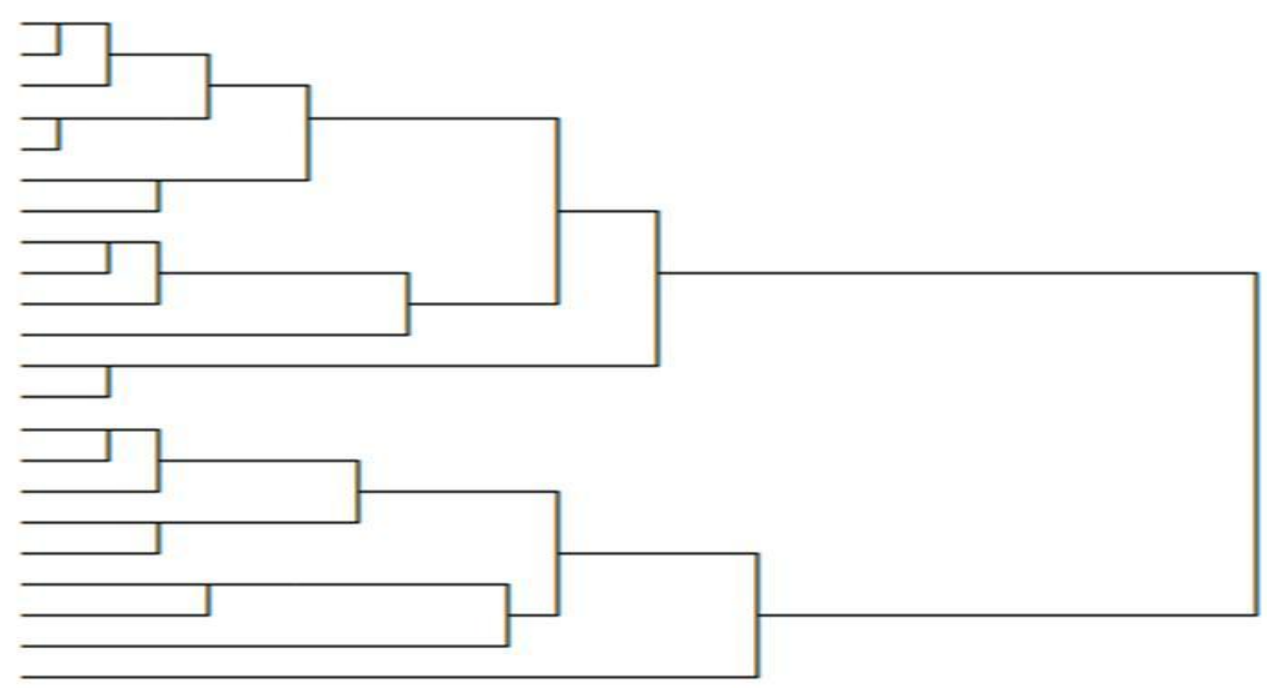


Table.1 Standard methods adopted for petiole nutrient analysis

\begin{tabular}{|c|c|c|c|}
\hline Nutrient & Method & Instrument & Reference \\
\hline Nitrogen & Kjeldhal digestion method & Kjeldhal distillation & \multirow{5}{*}{ Piper, 1966} \\
\hline Phosphorous & $\begin{array}{l}\text { Vanadomolybdate complex } \\
\text { method }\end{array}$ & Spectrophotometer & \\
\hline Potassium & Emission spectrometry & Flame photometer & \\
\hline Calcium and magnesium & EDTA titration & - & \\
\hline Sulphur & Turbidometry method & Spectrophotometer & \\
\hline $\begin{array}{l}\text { Iron, zinc, manganese and } \\
\text { Copper }\end{array}$ & Absorption spectrometry & AAS & $\begin{array}{l}\text { Lindsay and } \\
\text { Norvell, } 1978\end{array}$ \\
\hline
\end{tabular}

The petioles of Crimson Seedless belonging to coloured grapes recorded least zinc content (73.92 ppm) while, $111.25 \mathrm{ppm}$ of zinc was observed in table purpose white Manik Chaman grape variety. Among three major groups, table purpose white grape types recorded highest zinc $(100.98 \pm 10.56 \mathrm{ppm})$ while, least zinc content $(90.22 \pm 8.51 \mathrm{ppm})$ was recorded in wine grape type. Petiole $-\mathrm{Zn}$ content did not differ significantly among 3 grape type.

The copper content in grape petioles ranged from $11.23 \mathrm{ppm}$ in Tempranillo variety of wine grape type to $29.97 \mathrm{ppm}$ in Manik Chaman of table purpose white grape type. Among three broad grape categories, petiole copper content was found very highest in table purpose coloured petioles $(26.28 \pm 3.33$ ppm) and it was slightly lesser in table purpose white group $(25.67 \pm 4.11 \mathrm{ppm})$. Least copper content was recorded in petioles of wine grape varieties $(15.34 \pm 3.21 \mathrm{ppm})$. Petiole copper contents were found in the order: table coloured $=$ table white $>$ wine grape type.

Nitrogen, phosphorus and potassium contents in petioles of different grape types revealed that the table purpose white and coloured grape types recorded higher values compared to the wine grape petioles (Table 3). Among secondary nutrients, the petiole-Ca content was found very high in wine grapes while, it was low in table grape petioles. However, petiole- $\mathrm{Mg}$ and $\mathrm{S}$ contents were different in all the three grape types in the order white table grape $>$ wine grape >coloured table grape. The micronutrients ( $\mathrm{Fe}, \mathrm{Mn}, \mathrm{Zn}$ and $\mathrm{Cu}$ ) in table purpose white grape petioles were higher compared to wine grape petioles.

The petiole nutrient contents of all the grape types were subjected to hierarchical cluster analysis (Figure 1). It was interesting to note that there were two distinct clusters. The first cluster was found to be with all wine grape types and two coloured table purpose types namely, Crimson seedless and Red globe. Second cluster was comprised of all the table purpose white and coloured grape types (except the above two). These results suggested that the petiole nutrient contents of wine type are distinctly different and can be used as a tool to evaluate the grape types. Similar techniques of reports on petiole nutrient contents have been made use by Rauof (2015) for comparing different grape genotypes.

\section{References}

Bertoni, G., and Morard, P., 1982. Blade or Petiole Analysis as a Guide for Grape Nutrition. Comm in Soil Sci and Pl Analysis. 13: (8) 593-605.

Bhargava B.S. 2001. Annual Report, Maharashtra State Grape Growers 
Association, Pune.

Cook, J.A., T. Kinsaba. 1956. Petiole analysis as a criterion of nitrogen needs in California vineyards. Proc. American. Soc. Hortic. Sci. 68:131-140.

Kliewer, W.M. 1991. Methods for determining the nitrogen status of vineyards. In: J.M. Rantz (ed.), Proc. Inter. Symp. On Nitrogen in Grapes and Wine, Seattle, W. A., 18-19 June, 1991. American. Soc. Enol. Vitic.Davis, CA. pp. 133-147.

Lindsay, W. L and Norvell, W. A., 1978. Development of a DTPA soil test for $\mathrm{Zn}, \mathrm{Fe}, \mathrm{Mn}$ and $\mathrm{Cu}$. J. American. Soil Sci. Soc., 42: 421-428.

Marschner, H., 1995. Mineral Nutrition of Higher Plants, $2^{\text {nd }}$ ed. Academic, London, 889.

Patel, V.B. and Chadha, K.L., 2002. Effect of sampling time on the petiole nutrient composition in grape (Vitis vinifera L.). Indian J. Hort. 59 (4): 349-354.

Piper, C. S., 1966. Soil and Plant Analysis.
Han's Publication, Bombay.

Rauof, F., 2015. Evaluation study of some table grape genotypes selected from Khatroum orchards. J. Net. Comm. and Emerging Tech. 2: (2) 9-15.

Ruel, J. J. and Walker, M. A. 2006. Resistance to Pierce's disease in Muscadinia rotundifolia and other native grape species. American. J. Enol. Vitic.57: 158-165.

Thapar, A.R., 1960. Horticulture in the hill regions of North India. Directorate of Extension, Ministry of Food and Agriculture, New Delhi.

Zoë Migicovsky, Jason Sawler1, Kyle M Gardner, Mallikarjuna K Aradhya, Bernard H Prins, Heidi R Schwaninger, Carlos D Bustamante, Edward S Buckler, Gan-Yuan Zhong, Patrick J Brown and Sean Myles. 2017. Patterns of genomic and phenomic diversity in wine and table grapes. Hort Res.4: 3541.

\section{How to cite this article:}

Anita E. Kondi, Shankar Meti, B.V. Champa and Nagaraja, M.S. 2018. Comparison of Petiole Nutrient Contents of Different Table and Wine Grape Varieties. Int.J.Curr.Microbiol.App.Sci. 7(01): 447-453. doi: https://doi.org/10.20546/ijcmas.2018.701.052 